mos provenientes determina melhor o que somos, aqui e agora". Se nos estendemos sôbre o primeiro trabalho de E. de Martino, é porque êle não só assinala a retomada e a renovação dos estudos etnológicos na Itália, mas representa igualmente uma posição programática à qual o autor permanecerá fiel. De fato, daí a sete anos, com Il mondo magico (Prolegomeni ad una storia del marxismo), Turim, 1948, tentava interpretar històricamente a magia como contribuição válida para a formação do neohumanismo moderno. Não só, mas na intenção devia também submeter à análise o modo ocidental de aproximar-se dela. Em outras palavras, quis principalmente caracterizar o problema em tôrno do qual a magia se desenvolvera, e a função que, como idade histórica, exercera no quadro geral da civilização humana. Tentativa admirável, e embora susceptível de reservas, extremamente fértil.

Chega-nos às mãos o último trabalho do etnólogo italiano, Morte e pianto rituale viel mondo antico. Prosseguindo na linha traçada pelos dois volumes anteriores, de Martino estabelece conexões diretas entre restos arcaicos ainda presentes nos prantos rituais da Lucânia e da Transsilvânia e o lamento fúnebre das antigas religióes euromediterrâneas. Ocupa o primeiro plano uma tese ou descoberta já presente em Il mondo magico: de que o risco de "não existir mais no mundo" como presença leva à crise desta mesma presença. Noutros têrmos, a partir da análise do horror da morte como risco de "passar com o que passa", sem margem de autonomia formal, e por isso escapar ao mundo dos valores, caindo, pois, fora de qualquer história humana, chega-se a uma opção em prol da vida, na qual a morte se configura como condição para explicar a eterna fôrça regenerativa da cultura.

Através de considerações sôbre as técnicas mítico-rituais das civilizações religiosas do mundo antigo, de Martino põe a descoberto laços intrínsecos entre, de um lado, o pranto pela morte de pessoas históricas e, de outro, o lamento arquétipo pela morte de heróis míticos, sem dúvida ligado intimamente com as "paixões" ou momentos críticos decorrentes dos ciclos sazonais e agrícolas. Na crise da falta de presença e no luto insere-se, pois, nas antigas civilizações mediterrâneas, a instituição do lamento fúnebre ritual como uma das fôrças culturais mais importantes para combater essas mesmas crises, antes que o Cristianismo inaugure seu novo ethos da vida e da morte.

Esta última publicação de E. de Martino, trabalho de grande alento, que julgamos perfeito do ponto de vista metodológico, nos parece incrementar a problemática bistoricista, abrindo em profundidade uma visão clara e nova das relações que devem existir entre filosofia, etnologia e história. Cremos, porém, ser necessário assinalar um relativo desequilíbrio no tocante à focalização psicológica, que, embora sendo de vulto, se revela às vêzes um tanto apressada e arbitrária.

\title{
Armando Ferrari
}

ROGER BASTIDE: Les Religions Africaines au Brésil (Vers une sociologie des interpénetrations de civilisations). 578 págs. Presses Universitaires de France.

Paris, 1960

Durante todo o período da escravidão, malgrado advertências governamentais e principalmente religiosas, fecharam os senhores os olhos para as manifestações dos cultos nativos negros, que continuaram assim a existir; seu exercício era uma garantia para a paz racial. Candomblé, pajelança, macumba, constituíam válvulas de escape para a energia dos escravos, impedindo-os de se voltar contra a camada dominante, muito inferior em quantidade à camada negra. No entanto, a sobrevivência se dava 
sob a capa do catolicismo, ora disfarçado como maneiras nativas de louvar o Senhor, ora se realizando misteriosamente à noite ou em pontos periféricos e pouco vigiados das concentrações urbanas. Enquanto, para os senhores, a religião negra era um instrumento para manter submissos os negros, para êstes ela constituía um símbolo de fidelidade aos antepassados, assim como uma maneira de conservar a cultura e, até mesmo, de se opor aos brancos.

Com a abolição, incorporada a população escrava ao conjunto dos cidadãos brasileiros, verificou-se que os cultos negros, em lugar de desaparecer (uma vez que perdiam a função anteriormente desempenhada), floresceram decididamente, ganhando novo impulso e importância. Explicou-se esta persistência por terem êles alcançado nova função. A abolição não trouxera a incorporação pretendida, mas relegara os antigos escravos a uma condição inferior ainda à das camadas mais baixas da população. Desprovidos de preparo para afrontar a concorrência dos homens livres de nível inferior, não podendo entrar no mesmo pé que êstes no mercado de trabalho, vagabundagem e prostituição foram o destino dos antigos pajens e das antigas mucamas.

A estrutura hierarquizada da religião negra, com as variadas posições que internamente oferece a seus membros, veio representar para êstes indivíduos um meio em que não só poderiam subir socialmente e exercer cargos de chefia, como também encontrar auxílios, conselhos, remédios.

No entanto, à medida que se desenvolve o país, aquela integração que não se dera no momento da abolição vai se efetuando; ao mesmo tempo que negros vão conseguindo galgar certas posições sociais dentro das classes inferiores, brancos se degradam. As religiões negras sofrem modificação paralela em seu significado; representando agora compensação para uma classe oprimida, e não mais constituindo símbolo de determinada cultura, perdem um de seus caracteres - o de se prenderem a determinada etnia, a etnia negra, - para caracterizarem um grupo típico das camadas inferiores numa so- $^{-}$ ciedade de classes. Indivíduos de pele clara e mesmo brancos ingressam nesses grupos religiosos, utilizando-os na mesma medida e com o mesmo sentido da população negra.

Este é o resumo das transformações por que passaram as religiões negras entre nós. No entanto, não é apenas no tempo que elas apresentam mudanças, e sim também no espaço. Conforme a distribuição espacial negra, encontramos diferentes tipos de grupo religioso. Assim, enquanto nas cidades litorâneas, em que a concentração escrava foi grande, os cultos nativos puderam conservar muito mais sua pureza primitiva, no interior do país, onde a quantidade de escravos era muito menor, mesclaram-se êles com aborígenes e caboclos, o que, no plano cultural, deu em resultado a formação de religiões negras sincréticas. O sincretismo é aqui muito mais profundo do que no litoral. No litoral, há justaposição de elementos católicos e negros, que pouco a pouco vão se interpenetrando; no interior, há desde logo fusão, dando como resultado seitas mistas.

O problema capital colocado pelo transplante dos cultos negros para o Brasil deriva do seguinte: uma vez que a estrutura social é o suporte de tôda cultura, como puderam conservar-se tais cultos? Pois os negros transportados para cá viram destruída tôda a estrutura de seus grupos, e aqui foram submetidos a outra diferente. Neste estudo, Roger Bastide mostra como a herança cultural que um povo transporta consigo procura, dentro de uma nova configuração estrutural, os "nichos" em que possa se inserir. E, a partir dessa inserção, produz então as posições que faltam para tornar a. formar uma estrutura social, que passará a ser o apoio da cultura desenraizada, permitindo-lhe sobreviver. 
O problema, tal como se coloca entre nós, não pode ser abordado através do ponto de vista marxista; não temos uma infra-estrutura produzindo uma superestrutura ideológica; o que temos é uma superestrutura ideológica que se transporta para o Brasil por intermédio de indivíduos que perderam verdadeiramente o seu grupo. Na terra estranha, a partir da ideologia religiosa que foi transportada, é que se vai formar o novo grupo, que assim se estrutura ao contrário da tese marxista: a superestrutura produz uma infra-estrutura...

Como se vê, também não segue o Autor uma perspectiva culturalista; a sobrevivência da religião negra não é buscada em si mesma, mas explicada pela organização social que aqui se criou e na qual encontrou então seu ponto de apoio. No estudo das civilizações em presença, Roger Bastide toma sempre como base e ponto de referênia as configurações estruturais dos grupos que suportam essas civilizações. E é dentro de tal preocupação constante que verifica a adequação e redefine conceitos tais como o de reinterpretação cultural, de memória coletiva, de participação, formulando também um conceito complementar dêste último, a que dá o nome de "princípio de separação" (principe de coupure).

Como se vê, trata-se de um trabalho de grande importância para o Brasil - pois arialisa fatos sociais brasileiros - e para a Sociologia em geral - um vez que revê e amplia, à luz do cotejo com a realidade social, conceitos por ela formulados.

\section{Maria Isaura Pereira de Queiroz}

FELíCITAS BARReTO: Danzas Indígenas del Brasil. Prólogo de Miguel León Portilla. $\mathrm{XI}+138$ págs., com 50 fotografias fora do texto. Instituto Indigenista Interamericano. México, 1960.

Esparso pela copiosa literatura sôbre aborígenes brasileiros, há um sem-número de informes sôbre as danças encontradas nas diferentes tribos. Ninguém até hoje, ao que nos consta, se deu ao trabalho de sistematizar êsses elementos no intuito de apreciá-los num quadro de conjunto, discernindo entre o que nêles haja de comum e o que de específico distinga a coreografia de tal ou qual grupo em conexão com o respectivo sistema cultural. Em certo sentido, o volume de Felícitas Barreto poderia representar um primeiro passo nessa direção ou, pelo menos, um estímulo. Infelizmente, porém, foi escrito sem o necessário preparo científico. O Instituto Indigenista Interamericano, que se incumbiu de publicá-lo, deu-lhe luxuosa apresentação material, enriquecendo-o com a reprodução de numerosas fotografias, algumas excelentes.

Declara a autora que procurou imprimir a seu trabalho dois traços característicos: "Desejo que seja o mais fiel possível e que reflita de algum modo o profundo carinho que sinto pelo indígena brasileiro". Quanto ao segundo ponto, acrescenta: "E creio estar solidária com os sentimentos, não apenas de meus compatriotas brasileiros, mas de todo homem de boa vontade, ao afirmar que é necessário incrementar a ação indigenista no sentido de impedir o desaparecimento de nossos irmãos nativos, que com suas tradições e suas danças maravilhosas nos ligam a um passado cultural que ainda sobrevive na selva". Todos os que compartilhamos dêsses sentimentos fazemos votos por que o volume contribua a seu modo para melhorar a deplorável situação em que se encontram os nossos silvícolas. No que diz respeito ao valor científico da obra, há nela muitas falhas que o comprometem sèriamente.

Numa breve introdução, escrita com viveza, e com ligeireza também, Felícitas Barreto procura delinear os contornos gerais do "mundo indígena do Brasil". Nessas 